\title{
Ecology of the Invasive Red Alga Gracilaria salicornia (Rhodophyta) on O'ahu, Hawai ${ }^{\prime}{ }^{1}$
}

\author{
Fennifer E. Smith, ${ }^{2,3,4}$ Cynthia L. Hunter, ${ }^{3}$ Eric 7. Conklin, ${ }^{3,5}$ Rebecca Most, ${ }^{3,6}$ Thomas Sauvage, $e^{3,5}$ \\ Cheryl Squair, ${ }^{3,4}$ and Celia M. Smitb ${ }^{4}$
}

\begin{abstract}
The red alga Gracilaria salicornia (C. Agardh) E. Y. Dawson was introduced intentionally to two reefs on O'ahu, Hawai'i, in the 1970s for experimental aquaculture for the agar industry. Some $30 \mathrm{yr}$ later, this species has spread from the initial sites of introduction and is now competing with native marine flora and fauna. The goals of this study were to quantify various aspects of $G$. salicornia ecology in Hawai'i in an effort to develop control or eradication tools. Experimental plots were established to determine cover and biomass of $G$. salicornia per square meter and to determine the amount of time and person hours needed to remove $G$. salicornia from these plots. Substantial amounts of $G$. salicornia become dislodged from the reef during large wave events and periodically become deposited onto the beach in front of the Waikiki Aquarium. Algal beach wash biomass was quantified and positive relationships were established between swell height and the amount of algae that washed up onto the beach in this location. We then quantified the ability of $G$. salicornia vegetative fragments to regrow after desiccation to determine if algal biomass stranded on shore survives the tidal cycle until being washed back out on the reef at high tide. Gracilaria salicornia was remarkably resistant to temperature, salinity, and chemical treatments examined as possible in situ control options. Herbivore preference tests showed that a native Gracilaria species is consumed far more frequently than the alien congener. Finally, large-scale community volunteer efforts were organized to remove drifting $G$. salicornia fragments from the reef area in front of the Waikiki Aquarium. Over $20,000 \mathrm{~kg}$ of alien algal fragments were removed from this location in five 4-hr cleanup events. However, based on G. salicornia growth rates, ability to fragment, physical tolerance, and low herbivory, it is clear that a large-scale dedicated effort will be needed to control this invasive species on Waikikì's reefs.
\end{abstract}

THE LARGE-SCALE introduction of nonindigenous species is among the greatest threats to the homogenization of the world's biota and subsequent reduction in global biodiversity (Carlton and Geller 1993, Maragos et al. 1996, Ruiz et al. 1999). Hawaiian ecosystems

${ }^{1}$ Funding for this research was provided by the $\mathrm{Na}$ tional Oceanic and Atmospheric Administration Hawai'i Coral Reef Initiative Research Program Grant no. NA160A1449 awarded to C. L. Hunter and C. M. Smith. Manuscript accepted 27 May 2003.

${ }^{2}$ Corresponding author: Department of Botany,

Pacific Science (2004), vol. 58, no. 2:325-343

(C) 2004 by University of Hawai'i Press have been particularly impacted by the introduction of nonindigeous plants, invertebrates, birds, and mammals, with approximately $22 \%$ of the state's biota considered to be alien (Eldredge and Smith 2001). In many cases, terrestrial introductions have either directly

University of Hawai'i at Mānoa, 3190 Maile Way, Honolulu, Hawai'i 96822 (phone: 808-956-3943; fax: 808956-3923; E-mail: jesmith@hawaii.edu).

${ }^{3}$ Waikīki Aquarium, University of Hawai'i, $2777 \mathrm{Ka}-$ lākaua Avenue, Honolulu, Hawai'i 96815.

${ }^{4}$ Department of Botany, University of Hawai' $i$ at Mānoa, 3190 Maile Way, Honolulu, Hawai'i 96822.

${ }^{5}$ Department of Zoology, University of Hawai' $i$ at Mānoa, McCarthy Mall, Honolulu, Hawai'i 96822.

${ }^{6}$ Department of Oceanography, University of Hawai'i at Mānoa, 100 Pope Road, Honolulu, Hawai' $i$ 96822. 
or indirectly led to extinctions and threatened or endangered listings (Stone 1999). Because Hawai'i has extremely high rates of endemism, many of the species found within the archipelago are highly specialized and therefore very susceptible to invasion. Generalist invaders often overrun native specialists, leaving the highly unique endemic species in a vulnerable and threatened position (Stone 2002).

Less is known about rates of endemism in the Hawaiian marine environment but estimates suggest that a quarter of the flora and fauna in Hawai' $i$, including seaweeds, invertebrates, fish, and corals, is endemic (Eldredge and Smith 2001). Unlike many other tropical locales, the Hawaiian Islands have also received a number of nonindigenous marine species over the last century (Russell 1992, Coles et al. 1999, Eldredge and Smith 2001, Friedlander et al. 2002). Perhaps because Hawai' $i$ lies in the middle of the Pacific Ocean and is located on shipping routes across the Pacific, the Islands have intercepted more nonindigenous marine species than other tropical locations (Carlton 1987). The estimated number of nonindigenous marine species in Hawai' $i$ includes 287 invertebrates, 20 algae, 20 fish, and 12 flowering plant species (Eldredge and Smith 2001). Although the majority of nonindigenous marine species in Hawai' $i$ are invertebrates, many of these species are cryptic and/or have remained in highly disturbed harbor and other fouling environments. These factors have made it difficult to determine the impacts and interactions that the invaders may be having on native marine flora and fauna. However the larger and more conspicuous nonindigenous marine algae have become increasingly more common along Hawaiian shores over the last several decades (Smith et al. 2002).

Nonindigenous marine algae have had widespread and well-documented impacts in temperate locales around the world (Hanisak 1980, Carlton and Scanlon 1985, Meinesz et al. 1993, Trowbridge 1995, Bellan-Santini et al. 1996, Critchley et al. 1997, Ferrer et al. 1997, Andrew and Viejo 1998, Karlsson and Loo 1999, Jousson et al. 2000, Schaffelke et al. 2000), and some invasive (weedy, bloom forming) but native seaweed species have been documented in the Tropics (Smith et al. 1981, Stiger and Payri 1999a,b). Several species of nonindigenous marine algae have been introduced to the Hawaiian Islands both intentionally and unintentionally since the 1950s but little research has been conducted on the impacts of these species on the native reef community. Based on recent surveys conducted throughout the main Hawaiian Islands, five nonindigenous marine algae are currently recognized as being invasive (Smith et al. 2002). Three genera of red algae in particular were intentionally introduced to open-reef ecosystems for experimental aquaculture for the carageenan and agar industry in the mid-1970s and all are now considered to be nuisance species on Hawai'i's reefs.

Hypnea musciformis (Wulfen) J. V. Lamouroux was introduced from Florida to Kāne'ohe Bay, O'ahu, in 1974. This species is now the second most widespread of the nonindigenous marine algae species in Hawai' $i$ and is found on all of the main islands except the island of Hawai' $i$. This alga forms massive blooms on the island of Maui (Hodgson 1994), and a recent economic evaluation has estimated that because of the algal blooms, the state of Hawai'i suffers net losses of over $\$ 20$ million per year due to reduced occupancy rates in hotels and condominiums, reduced property value, and direct costs of removing rotting seaweed from beaches $(\mathrm{Ce}-$ sar et al. 2002).

Kappaphycus alvarezii (Doty) Doty ex P. C. Silva and K. striatum (F. Schmitz) Doty ex P. C. Silva were introduced to Honolulu Harbor and Kāne'ohe Bay throughout the 1970s (Russell 1983). Recent surveys suggest that these species remain largely restricted to $\mathrm{Ka}-$ ne'ohe Bay proper, but $K$. alvarezii has become an ecological dominant on some patch, fringing, and back reef habitats. Observations suggest that these species are overgrowing and killing coral (Woo 2000), but more longterm data are needed to substantiate these observations.

Gracilaria salicornia (C. Agardh) E. Y. Dawson was introduced to Waikīkī and Kāne'ohe Bay in 1971 and 1978, respectively, from a population that had been known from 
the island of Hawai' $i$ before the 1950s. There is some support for the idea that this Hawai' $i$ Island population was an early twentiethcentury ballast introduction from ships originating from the Philippines (where $G$. salicornia is native [I. Abbott, pers. comm.]). Once on $\mathrm{O}^{\prime} \mathrm{ahu}, \mathrm{G}$. salicornia was brought to Pūko'o, Moloka'i, where G. parvispora Abbott was being cultivated for food consumption. Surveys conducted in 1999 (Smith et al. 2002) determined that $G$. salicornia still had a distinct and localized distribution throughout the Hawaiian Islands. At that time, G. salicornia was highly successful and abundant in areas where it had been initially introduced some $30 \mathrm{yr}$ earlier, but there was no continuity between populations, suggesting that it could not successfully colonize new areas without human intervention. Since the surveys conducted by Smith et al. (2002) in 1999, observations of new populations have been documented (J.E.S., unpubl. data), suggesting that this species may be becoming increasingly successful on Hawai'i's reefs.

Very limited research has been conducted on the ecology of G. salicornia in both its native and nonindigenous ranges. However, evidence suggests that the unique mat-forming morphology of this species provides physiological adaptations allowing the species to tolerate a wide range of light environments (Beach et al. 1997) while also monopolizing nutrients that may be seeping from underlying sediments (Larned 1998). Fragmentation appears to be the primary mode of reproduction for G. salicornia in Hawai'i (Smith et al. 2002) as evidenced by the genetic similarity of the entire Waikiki population and because sexual reproduction has rarely been observed (Nishimura 2000). Because of its large morphological stature and dense mats $5-10 \mathrm{~cm}$ thick, $G$. salicornia can have profound effects on benthic ecology by simply monopolizing substrata. This is particularly evident in areas such as Waikīki where $G$. salicornia has become the single-most dominant benthic species in an area that before invasion was home to over 60 species of macroalgae (Doty 1969). Because of the impacts that this species may have on Hawai'i's reef ecosystems, the goals of our study were to gain a better under- standing of the ecology of $G$. salicornia in Waikiki and to investigate strategies that may be useful in its control.

\section{MATERIALS AND METHODS}

\section{Reconnaissance Surveys}

Gracilaria salicomia was initially planted on the reef in front of the War Memorial Natatorium in Waikīki and at the Hawai'i Institute of Marine Biology (HIMB), O'ahu, Hawai'i (see Figure 1). Surveys conducted in 1996 (Rodgers and Cox 1999) and 1999 (Smith et al. 2002) found that although G. salicornia appeared to have spread within Kāne'ohe Bay no new populations were found outside the bay. To gain a better understanding of the current distribution of $G$. salicornia on $\mathrm{O}^{\prime} \mathrm{ahu}$, broad qualitative reconnaissance surveys were conducted. To determine the extent of the Waikiki population, snorkelers began at the Natatorium (see Figure 2) and swam both east and west to determine where the population ended. During all surveys, snorkelers were approximately $10 \mathrm{~m}$ apart and swam from shore to the reef crest. Using laminated high-resolution aerial photographs (http:// biogeo.nos.noaa.gov) snorkelers could determine and record locations where $G$. salicornia was sighted. After swimming one reef swath, snorkelers moved about $10 \mathrm{~m}$ up or down the shore and swam back. Notes regarding the extent of new patches (continuous cover to small isolated patches) were recorded. Similar surveys were also conducted at Kualoa Beach Park and Hawai'i Kai, O'ahu, Hawai'i (see Figure 1).

\section{Beach Wash Biomass}

Large amounts of $G$. salicornia often wash up onto beaches in Waikiki following large south swells (J.E.S., pers. obs.), particularly the beach fronting the Waikikī Aquarium and Waikikīs Marine Life Conservation District (MLCD) (see Figure 2, $A$ ). Linear regression was used to test whether there was a relationship between swell height and the amount (area and weight) of algae on the beach. Algal beach wash was quantified by measuring the 
area of each large mound of algae on the beach at low tide. The total length of each mound was measured along the long axis of the beach and widths were measured every 2 $\mathrm{m}$. Wet weight biomass was then estimated by collecting all algae from within a $0.16-\mathrm{m}^{2}$ quadrat every $5 \mathrm{~m}$ in the center of a mound. Algae in direct contact with sand were rinsed and drained using a sieve and spun in a mesh bag to remove water evenly. Algae were then sorted into two categories, G. salicornia or "other," and each was weighed.

\section{Field Growth Rates}

To assess growth rates of $G$. salicornia in the field and to determine if the beach wash algae remained viable after desiccation at low tide, growth experiments were conducted on the reef in front of the Natatorium in Waikiki (see Figure 2,B). Ten individuals were collected haphazardly from the reef and from beach wash (midmound) at low tide (desiccation had occurred for approximately $3 \mathrm{hr}$ ). Apical tips of the same size (1-2 cm long) and pigmentation were excised from fragments, blotted dry, and weighed. Each fragment was placed into an acrylic cup $(6$ by $10 \mathrm{~cm})$ with open plastic mesh (1/4 cm diameter) top and bottom. A pair of cups (beach wash and control fragments) was placed into a larger (30 by 15 by $13 \mathrm{~cm}, 1 \mathrm{~cm}$ diameter mesh) wire-mesh cage that was affixed to a temporary chain (1$1.5 \mathrm{~m}$ depth) attached to the reef bottom, running parallel to, and $42 \mathrm{~m}$ in front of, the Natatorium wall (see Figure 2,B). Cages were placed approximately $10 \mathrm{~cm}$ apart and were cleaned every 4 days by snorkelers to reduce sediment accumulation and biofouling. Fragments were collected, blotted dry, and weighed approximately every week for 2 months. A paired $t$-test was used to determine if there were significant differences in growth rates $(\mathrm{g} / \mathrm{g} /$ day from day 0 to day 62) between paired control and beach wash thalli.

To further quantify the effects of desiccation stress on $G$. salicornia a second growth experiment was conducted. A total of 40 fragments was collected from the reef as just described and 10 fragments were randomly selected for each of four levels of desiccation stress $(0,2,4$, and $6 \mathrm{hr}$ of drying in beach wash as estimated from perpendicular distance $0,10 \mathrm{~cm}, 1.2 \mathrm{~m}$, and $2.4 \mathrm{~m}$ from the waterline at low tide). After the desiccation treatments, fragments were grown on the reef as just described with one sample from each treatment placed together in a mesh cage (treated as a block) and growth was measured weekly for 4 weeks. A two-way analysis of variance was conducted to test for significant differences in mean growth rates (g/g/day) between the four levels of desiccation stress (fixed factor) and block (random factor).

\section{Grazing Pressure by Herbivorous Fishes}

Herbivore preference tests were conducted at HIMB in outdoor tanks with flowing seawater to determine if native herbivorous fish species have a dietary preference for native versus alien Gracilaria species (G. coronopifolia J. Agardh and G. salicornia, respectively). Fishes were collected in traps on the fringing reef surrounding HIMB. Fishes were removed from traps and immediately brought to the HIMB facilities, where each fish was placed into a separate flow-through 22.75liter aquarium. Fishes were left undisturbed without food overnight, with preference trials beginning the following day. A variety of acanthurid and scarid species was used in each of the herbivore preference trials. (See Figure $5 B$ for the specific fish species used.)

All algal material was collected from Checker Reef, a patch reef just north of HIMB the day before experimental trials and kept in outdoor tanks with flowing seawater. On the day of the test, thalli of each species were spun dry in a salad spinner and weighed to $0.001 \mathrm{~g}$. Thalli for each species pair were trimmed to roughly the same size to minimize any bias in preference due to the amount of algae of each species offered (Holmlund et al. 1990). Each weighed thallus was held in a clothespin fastened to a 7 by $7 \mathrm{~cm}$ concrete plate, and one thallus of each species was placed in each aquarium. Several pairs of thalli were placed in aquariums without fishes to serve as growth controls. Spatial arrangements of the thalli within the tank were randomized. At the end of the 24-hr 
trial period, all thalli were removed from aquariums, spun in a salad spinner, and reweighed, with consumption measured as the amount of each algal species consumed (weight loss) per gram of initial thallus weight per day, corrected for growth determined from controls. Two trials of the experiment were run in the winter of 2000. Twelve fishes were used in the first trial and 22 in the second, with a total combined sample size of 34 fishes. Preferences of fishes for different algal species were tested using methods developed by Peterson and Renaud (1989).

\section{Use of Temperature, Salinity, and Chemicals for Control}

Experiments were conducted at HIMB in outdoor seawater tanks to determine tolerance ranges of $G$. salicornia to a variety of temperature and salinity regimes as well as to various concentrations of commercial-grade herbicide and algicide. All algal material was collected from the lagoon at HIMB, cleaned of any epiphytes, spun 10 times in a salad spinner, and fresh weight was obtained. A total of three replicates was used for each treatment; each was placed in a separate 4.55liter aquarium located in an outdoor tank with natural lighting. For the temperature experiment, thalli were placed into the treatment conditions $\left(8,16,27,34\right.$, and $\left.41^{\circ} \mathrm{C}\right)$ for $1 \mathrm{hr}$ and then returned to ambient temperature $\left(27^{\circ} \mathrm{C}\right)$ with flow-through seawater; weights were again obtained after 1 week. For all other experiments, individual thalli were placed directly into the treatment for 1 week and then reweighed. Treatment conditions for the salinity experiment were $0,17,34,50$, and $75 \%$ and were maintained for the duration of the experiment. Two chemical treatments were examined-an herbicide (Ortho Triox-total weed killer) and an algicide (Pool Time). High and low doses were applied according to the individual chemical and were based on suggested applications on each bottle. Low doses were $124.8 \mathrm{ml} /$ liter and 0.0198 $\mathrm{ml} /$ liter and high doses were $254.6 \mathrm{ml} /$ liter and $0.264 \mathrm{ml} /$ liter for the herbicide and algicide, respectively. At the end of 1 week all thalli were wet weighed. Rapid light curves were obtained for all algal thalli using a pulse amplitude modulation fluorometer to estimate photosynthetic efficiency (White and Critchley 1999). Electron transport rates (ETR) were calculated from the equation: $\mathrm{ETR}=$ yield $\times$ PAR $($ Photosynthetically Active Radiation) $\times 0.5 \times 1$ (ETR factor). Maximum electron transport rates $\left(\mathrm{ETR}_{\max }\right)$, an estimate of maximum photosynthetic rates $\left(\mathrm{P}_{\max }\right)$, were calculated from these curves using nonlinear regression (Frenette et al. 1993). Linear regression was then used to test for relationships between growth and $\mathrm{ETR}_{\max }$.

\section{Manual Removal and Effects on Benthic Community Composition}

Three 30-m transects were established on the reef flat (1-2 $\mathrm{m}$ depth) directly in front of the Natatorium (see Figure 2,C-E). Transects were placed approximately $20 \mathrm{~m}$ seaward of the memorial wall extending toward the reef crest, running parallel to each other and approximately $25 \mathrm{~m}$ apart. Five points were selected randomly on each transect where paired $0.25-\mathrm{m}^{2}$ plots were permanently marked on either side of the transect with stainless-steel pins. Percentage cover was measured by snorkelers using the pointintercept method with a double-strung quadrat using a total of 36 intersections. In instances where canopy and understory algae were present, a single intersection was assigned two or more points depending on the number of species encountered; therefore, some quadrats had more than 36 points sampled. Surveys were conducted in November 2002.

After the benthic surveys, one quadrat in each pair was selected and all of the G. salicornia within the quadrat was removed completely. Snorkelers handpicked G. salicornia and placed all biomass into a large, plastic, fine-mesh bag while simultaneously fanning the water with a hand net to capture all fragments that were generated while removing larger pieces of the alga. When all or most of the large visible biomass was removed, forceps were used to scrape small attachment points from the substratum. Snorkelers 
recorded the type of habitat and the total amount of time required to remove all $G$. salicornia biomass per quadrat. Upon returning to the shore wet weights of the removed G. salicornia were measured for each plot. Surveys were repeated for 3 months after the initial removal of $G$. salicornia to determine rates of regrowth. Linear regression was used to test for relationships between removal time, biomass, and percentage cover.

\section{Volunteer-Based Removal Efforts}

A collaboration among researchers, students, managers, nongovernmental organizations, small businesses, and members of the local community was formed to address two objectives: (1) to assess the feasibility of largescale manual removal of the alien alga, $G$. salicornia, from a reef area and (2) to build constituency and public awareness of the threats of alien algae to Hawaiian reefs. However, because of the remarkable ability of this species to reproduce by vegetative fragmentation (Smith et al. 2002), there was substantial concern that a removal effort might in fact generate fragments, thereby perpetuating the problem. Instead of removing attached $G$. salicornia from the reef, these efforts were focused on removing the fragment pool (unattached and drifting) from the water, primarily the dredged trench that tends to accumulate massive amounts of algal biomass on the west end of the Natatorium (see Figure $2, F$ ). Algae had accumulated in the trench after physical disturbance tore large mounds loose from the adjacent reef.

Participants were initially contacted through nongovernmental organization Email lists (The Nature Conservancy, Reef Check), university classes, campus clubs, the University of Hawai'i Dive Safety Office, canoe clubs, Waikīkī Aquarium volunteers, and by word of mouth. T-shirts were printed and provided to each volunteer; refreshments and lunches were arranged through local vendors. Informational brochures and posters were prepared and displayed on tables at the cleanup site for passersby and participants alike.

Five nonindigenous algae cleanup events have been held from August 2002 to April 2003. Participation increased from 62 volun- teers at the first event to over 120 for the April 2003 cleanup. Permits for removal of algae from the MLCD were obtained from the Hawai'i Department of Land and Natural Resources and the City and County of Honolulu's Parks Department. Participants signed the permit and contact information sheets as they arrived at the site.

Participants were organized into five workgroups: scuba divers, snorkelers, beach workers, bag carriers, and sorters/weighers. University of Hawai'i certified research divers collected floating algae from the trench area ( 3-4 m depth) about $80 \mathrm{~m}$ from shore. Divers stuffed the algae into burlap bags that were then closed with a plastic zip tie. Snorkelers retrieved the filled bags from the divers and secured them to boogie boards with elastic cords. Bags were then floated on the boogie boards over the shallow reef flat to the beach. From the beach, bags were carried to a concrete ramp to drain and the boogie boards passed back to the waiting snorkelers.

Workers also collected and bagged G. salicornia from the beach wash. On the third, fourth, and fifth cleanups, a small-mesh seine net was used to haul floating algae from the shallow nearshore area up onto the beach where it was bagged and carried to the sorting area; this method of collection was very effective in removing large amounts of algae in a fairly short time.

After draining for a timed interval of 5 min, bags were weighed and then emptied onto tarps in the sorting area. Researchers and trained students removed select native algae that were mixed with the $G$. salicornia thalli and returned the native species to the reef. The nonindigenous marine algae (NIMA) biomass was transferred to a garbage bin that was later delivered to a local greenwaste recycling company for processing into composting tea. Some of the NIMA was provided to farmers directly for test use as compost in taro agriculture.

\section{RESULTS}

\section{Reconnaissance Surveys}

A continuous population of G. salicornia was documented in Waikìki from Diamond Head 


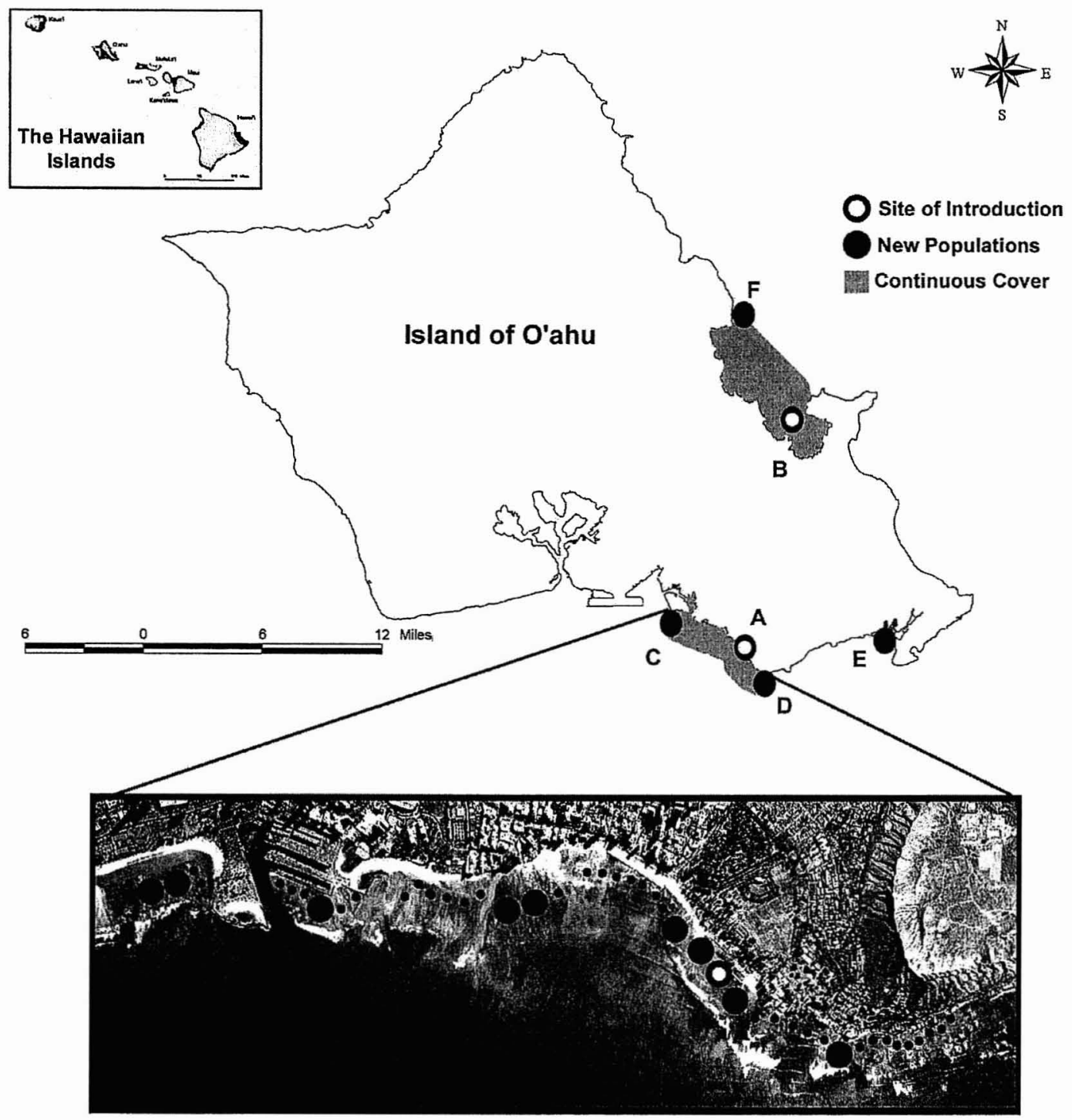

FIGURE 1. Distribution of G. salicornia in the main Hawaiian Islands (inset) and on the island of O'ahu. Black dots with white centers indicate the original sites of introduction, whereas solid black dots represent new populations. The shaded gray areas on the $O^{\prime}$ ahu map represent areas where G. salicornia is common throughout. Sites are indicated by letters as follows: $A$, Waikikī Natatorium; $B$, Hawai'i Institute of Marine Biology; $C$, Ala Moana Beach Park; $D$, Diamond Head; $E$, Hawaici Kai; $F$, Kualoa Beach Park. The lower photograph shows detail of the Waikiki area: large dots indicate continuous coverage (less than $5 \mathrm{~m}$ between adjacent patches) and small dots indicate smaller isolated patches (5-20 $\mathrm{m}$ between patches).

Beach Park to Ala Moana Beach Park (Figure $1)$. The majority of this area was characterized by small, scattered patches $0.5-3 \mathrm{~m}$ in diameter with from 5 to $20 \mathrm{~m}$ between patches. Other areas such as the Natatorium and the Waikìki MLCD had virtually continuous coverage of $G$. salicornia with usually less than 1-2 m between patches (Figure 2). Surveys continued from Diamond Head to Hawai'i Kai, where unattached drift was 


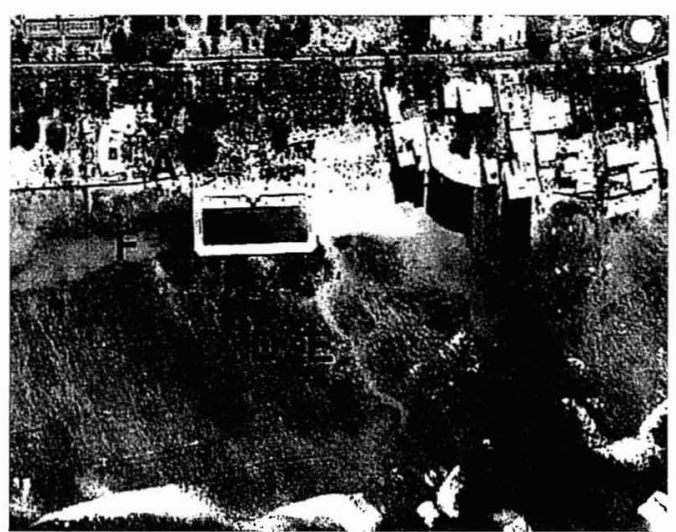

FIgURE 2. Map of the study area, including the War Memorial Natatorium (large rectangular body of water) and a section of the Waikiki Marine Life Conservation District (on the left side of the Natatorium). $A$, Beach area where beach wash experiment was conducted; $B$, reef area in front of the Natatorium where growth experiment was conducted; $C-E$, position of $30-\mathrm{m}$ transects and locations for removal experiments; $F$, dredged trench where divers removed unattached drift $G$. salicornia in volunteer cleanup events.

found at Wailupe Beach Park and an attached population was found at Paikō Lagoon, Hawai'i Kai, where several small $(<1 \mathrm{~m})$ patches were scattered across a $90-\mathrm{m}^{2}$ area. On the northeastern shore of $\mathrm{O}^{\prime} \mathrm{ahu}$, surveys conducted at Kualoa Beach Park documented a continuous population at the south end of the park in shallow water $(<1 \mathrm{~m}$ depth), but this population did not extend far over the reef flat (covering $<50 \mathrm{~m}^{2}$ in area). Gracilaria salicornia has also been found in Pearl Harbor on the southern shore (Coles et al. 1997), at Queen's Beach near Makapu'u on the eastern shore (R. Iwamoto, pers. comm.), near Wai'anae High School on the western shore (D. Adams, pers. comm.), and almost continuously throughout Kāne'ohe Bay (Rodgers and Cox 1999, Smith et al. 2002).

\section{Beach Wash Biomass}

Beach wash (mounds of unattached G. salicornia) was quantified on a total of 7 days where total beach area, biomass per square meter and total beach biomass were estimated. There was a positive association between swell height and total beach biomass, but this relationship was not significant at the $5 \%$ level (Figure $3 A$ ). Nevertheless all measured parameters tended to increase with increasing swell height (Figure $3 B$ ), suggesting that wave height has a positive affect on the biomass of $G$. salicornia that accumulates on the beach. Up to $1905 \mathrm{~kg}$ of wet-weight biomass was found on the beach at low tide during a $1.5-\mathrm{m}$ swell.

\section{Field Growth Rates}

Results of the paired $t$-test suggest that mean growth rates were not significantly different between control fragments and beach wash fragments that had been desiccated for $3 \mathrm{hr}$ after 60 days of growth in the field $(t=1.06$, $P=0.322$, mean of differences $=4.77,95 \%$ confidence interval: $-5.64,15.18)$. Figure $4 A$ shows growth rates of the two treatments over time and the largest visible difference in growth can be seen at the first time point, suggesting that the beach wash thalli may have initially been stressed from the desiccation treatment. For the remainder of the experiment, mean growth rates for the control thalli were slightly higher than those for the beach wash thalli, but this trend was not significant. Beach wash fragments grew on average $0.029 \mathrm{~g} / \mathrm{g} /$ day $( \pm 0.0026 \mathrm{SE})$ or $6.04 \%$ per day, whereas reef fragments grew $0.037 \mathrm{~g} /$ $\mathrm{g} / \mathrm{day}( \pm 0.0036 \mathrm{SE})$ or $10.77 \%$ per day (Figure $4 B$ ). Growth rates in both treatments changed over time, but this pattern was similar for all thalli, suggesting that the treatments responded similarly to temporal variation (Figure $4 A$ ).

Results from the desiccation experiment demonstrate significant effects for both the treatment (Figure $4 C, F=3.90, \mathrm{df}=3, P=$ $0.019)$ and the block $(F=3013, \mathrm{df}=9, P=$ 0.017 ) factors. Tukey's pairwise multiple comparison tests for the treatment factor showed significant differences between the control fragments and the 4- and 6-hr desiccation treatments $(P=0.026$ and 0.039 , respectively). Although differences in treatments were detected, all of the fragments still 

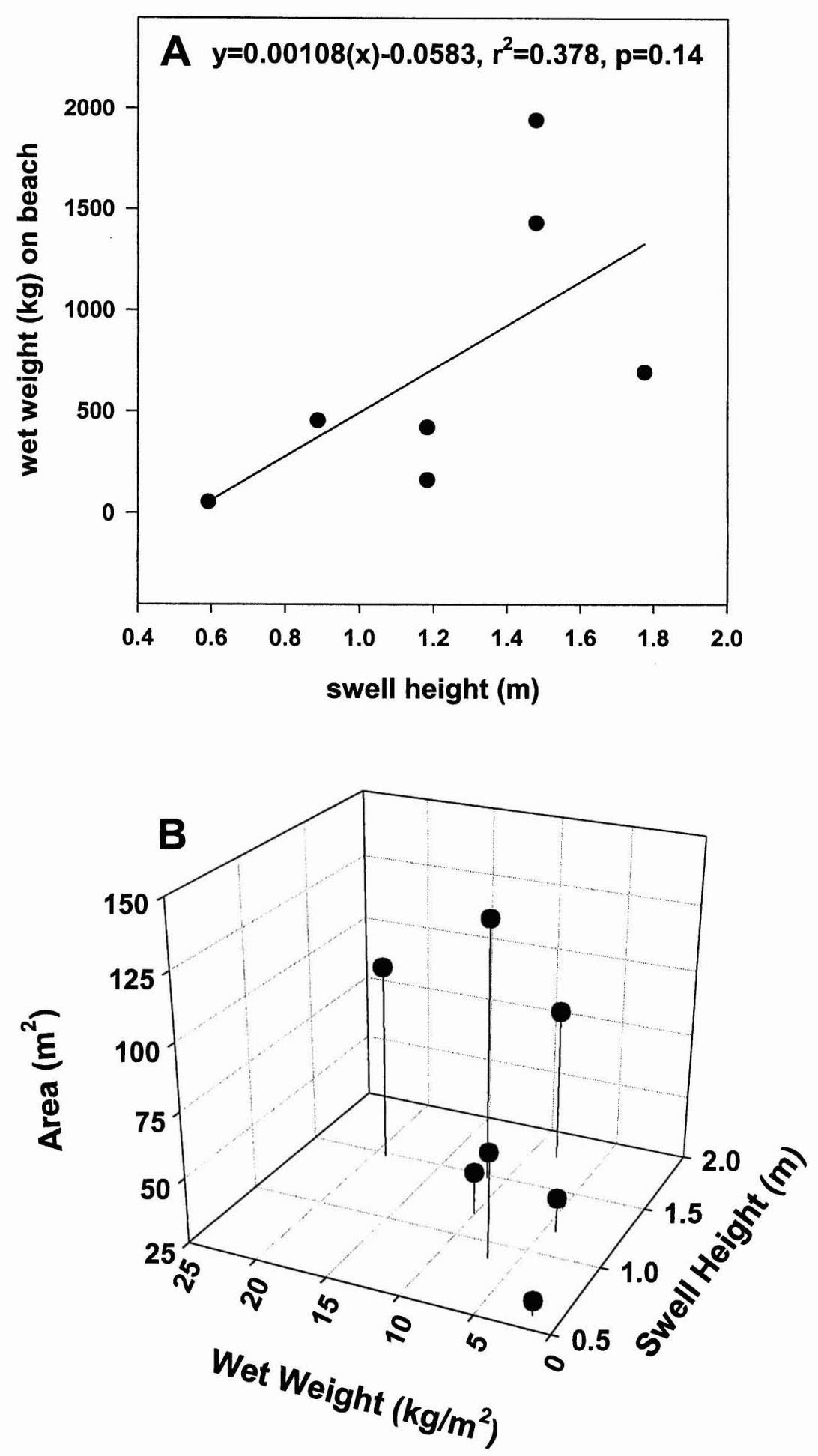

Figure 3. $A$, Linear regression of swell height $(\mathrm{m})$ and biomass of $G$. salicornia washed onto the beach in front of the Waikīkì Aquarium; $B$, relationship between swell height $(\mathrm{m})$, area of beach wash $\left(\mathrm{m}^{2}\right)$, and wet weight $\left(\mathrm{kg} / \mathrm{m}^{2}\right)$ of $G$. salicornia. 

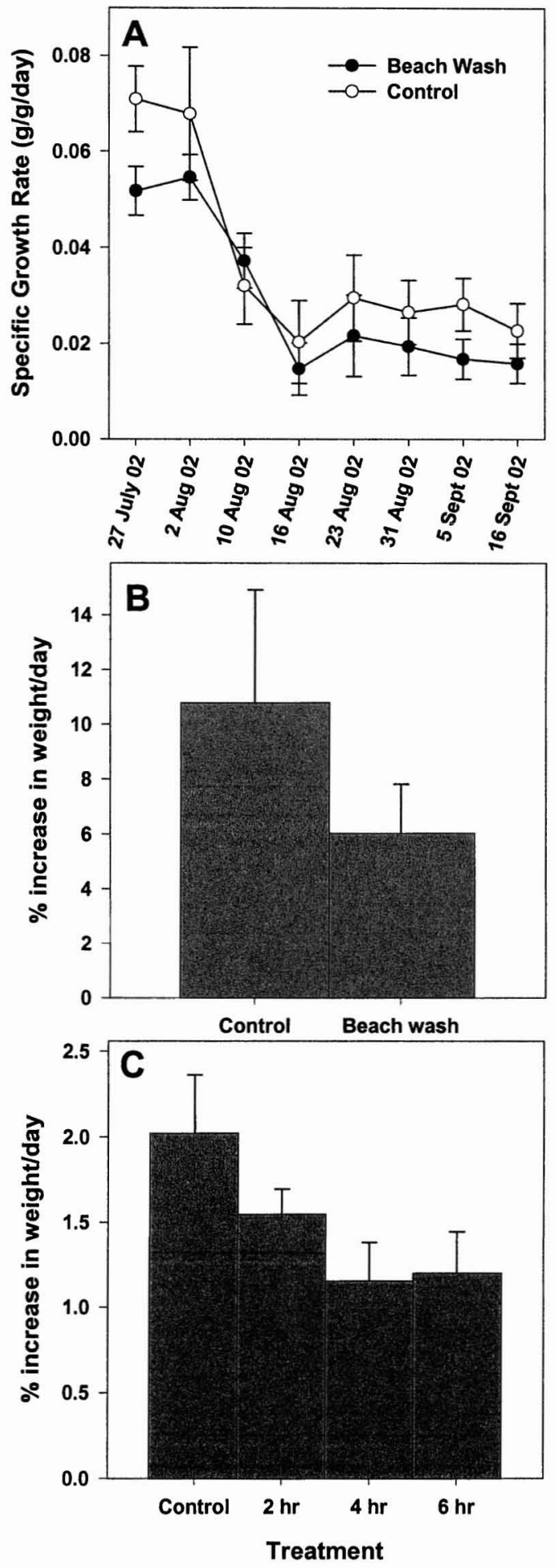

maintained positive growth at the end of the experiment and were therefore viable. Differences in growth rates between the blocks may have been the result of microscale variability within this reef environment.

\section{Grazing Pressure by Herbivorous Fishes}

Results of herbivore preference tests showed that the native $G$. coronopifolia was preferred as a food source over the nonindigenous $G$. salicornia (Figure $5 A$ ). Both runs of the experiment showed similar results, with the native Gracilaria consistently preferred over the alien. A two-sample $t$-test (as developed in Peterson and Renaud 1989) was used to determine whether differences in growth between the two species were significantly different in experimental (with herbivores) relative to control (no herbivores) runs (with mean $G$. salicornia growth subtracted from $G$. coronopifolia growth). Results of this test show that significantly more $G$. coronopifolia was consumed by hervivorous fishes than $G$. salicornia $(n=34 ; t=3.18, \quad \mathrm{df}=34, \quad P=$ $0.0031)$. Mean growth rates for $G$. coronopifolia were $0.0466 \mathrm{~g} / \mathrm{g} / \mathrm{day}( \pm 0.005,1 \mathrm{SE})$ and $-0.0995( \pm 0.044,1 \mathrm{SE})$ for the control and grazing assay, respectively, and growth rates for $G$. salicornia were $0.0461( \pm 0.003,1 \mathrm{SE})$ and $0.0283( \pm 0.007,1 \mathrm{SE})$. When examining grazing intensity by fish species there is some evidence to suggest that different herbivore families may show different preferences (Figure $5 B$ ). All of the species of acanthurids tested showed a consistent preference for the native Gracilaria species, but juvenile scarids, although consuming far less algal biomass than any other group, did not demonstrate a preference for either alga.

FIGURE 4. $A$, Growth rates of $G$. salicornia fragments collected from the reef (control) and from the beach (beach wash) at low tide after approximately $3 \mathrm{hr}$ of desiccation; $B$, average percentage increase in fragment size for each treatment per day (mean $\pm 1 \mathrm{SE}, n=9$ ); $C$, average percentage increase in fragment size per day for each of four desiccation treatments $(0,2,4$, and $6 \mathrm{hr}$ of drying, mean $\pm 1 \mathrm{SE}, n=10$ ). 

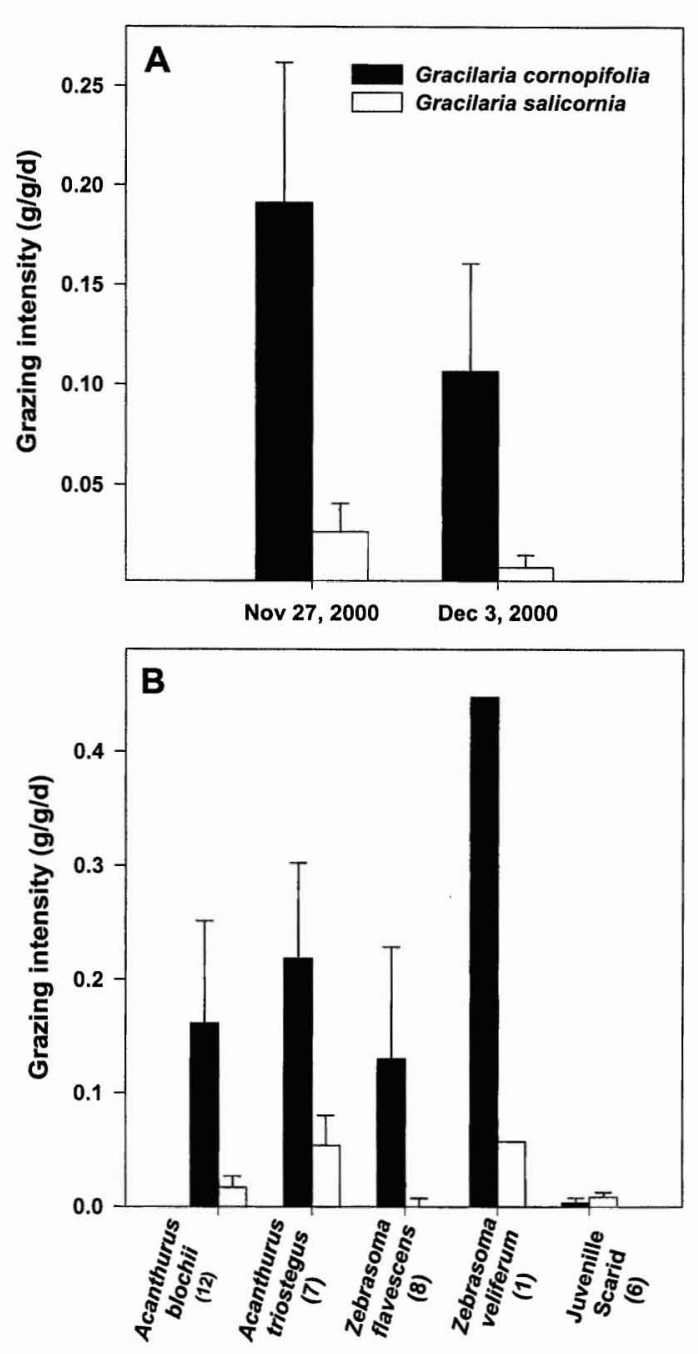

Fish Species

FIGURE 5. Grazing intensity by herbivorous fishes on two Gracilaria species (native, black bar; alien, white bar). $A$, Results of two grazing assays (mean $\pm 1 \mathrm{SE}, n=12$ and 22 , respectively); $B$, breakdown of grazing intensity results by fish species (mean $\pm 1 \mathrm{SE}, n$ for each fish species is shown in parentheses under species names).

\section{Use of Temperature, Salinity, and Chemicals for Control}

Gracilaria salicornia remained viable and maintained positive growth for all experimental treatments except for the extreme warm-water treatment $\left(41^{\circ} \mathrm{C}\right)$, the two high- salinity treatments (50 and $75 \%$ ), both high and low herbicide treatments, and the high algicide treatment (Figure 6A). Rapid light curves were obtained for all samples that were still intact to estimate photosynthetic rates at the end of the experiment. A significant positive relationship was found between growth and $\mathrm{ETR}_{\max }$, suggesting that photosynthetic rates can be used as a proxy for growth (Figure $6 B$ ). These analyses were also performed to validate the growth studies. There was concern that the freshwater treatment samples may not have grown and that positive weight gain was really the result of osmotic stress caused by extreme gradients between the alga and the surrounding medium. However, all $G$. salicornia were alive and photosynthetically competent after 1 week of immersion in the freshwater treatment, suggesting that this species is able to survive in this extreme environment.

\section{Manual Removal and Effects on Bentbic Community Composition}

Results of surveys from permanent transects established on the reef in front of the Natatorium showed that before removal, $G$. salicornia represented $47.78 \%$ of the benthic cover $( \pm 6.19 \mathrm{SE}, n=15)$. Immediately after removal, $G$. salicornia cover was reduced to $<1 \%$, by 2 weeks after removal had increased to $12.76 \%( \pm 2.21 \mathrm{SE})$, and 4 weeks after removal was up to $20.72 \%$ total cover $( \pm 3.30$ $\mathrm{SE})$. Control plots remained relatively constant over time but did increase in $G$. salicornia abundance by $5 \%$ over the same 4 week period (Figure 7).

Manual removal of $G$. salicornia biomass from the reef took on average $415.7 \mathrm{~min} / \mathrm{m}^{2}$ $( \pm 48.5 \mathrm{SE}, n=15)$, and there were no differences in time between different habitat types (rubble, crevices, and mixed, $F=1.49$, $\mathrm{df}=2, P=0.267$ ), but as percentage cover and/or biomass increased the time to clear also increased (Figure $8 A, B$ ). Mean biomass per square meter was $5.193 \mathrm{~kg}( \pm 6.36 \mathrm{SE}$, $n=15$ ) and also did not vary significantly with habitat type $(F=3.5, \mathrm{df}=2, P=$ $0.067)$. Percentage cover of $G$. salicornia $\mathrm{did}$ not vary with habitat type $(F=2.31, \mathrm{df}=2$, 

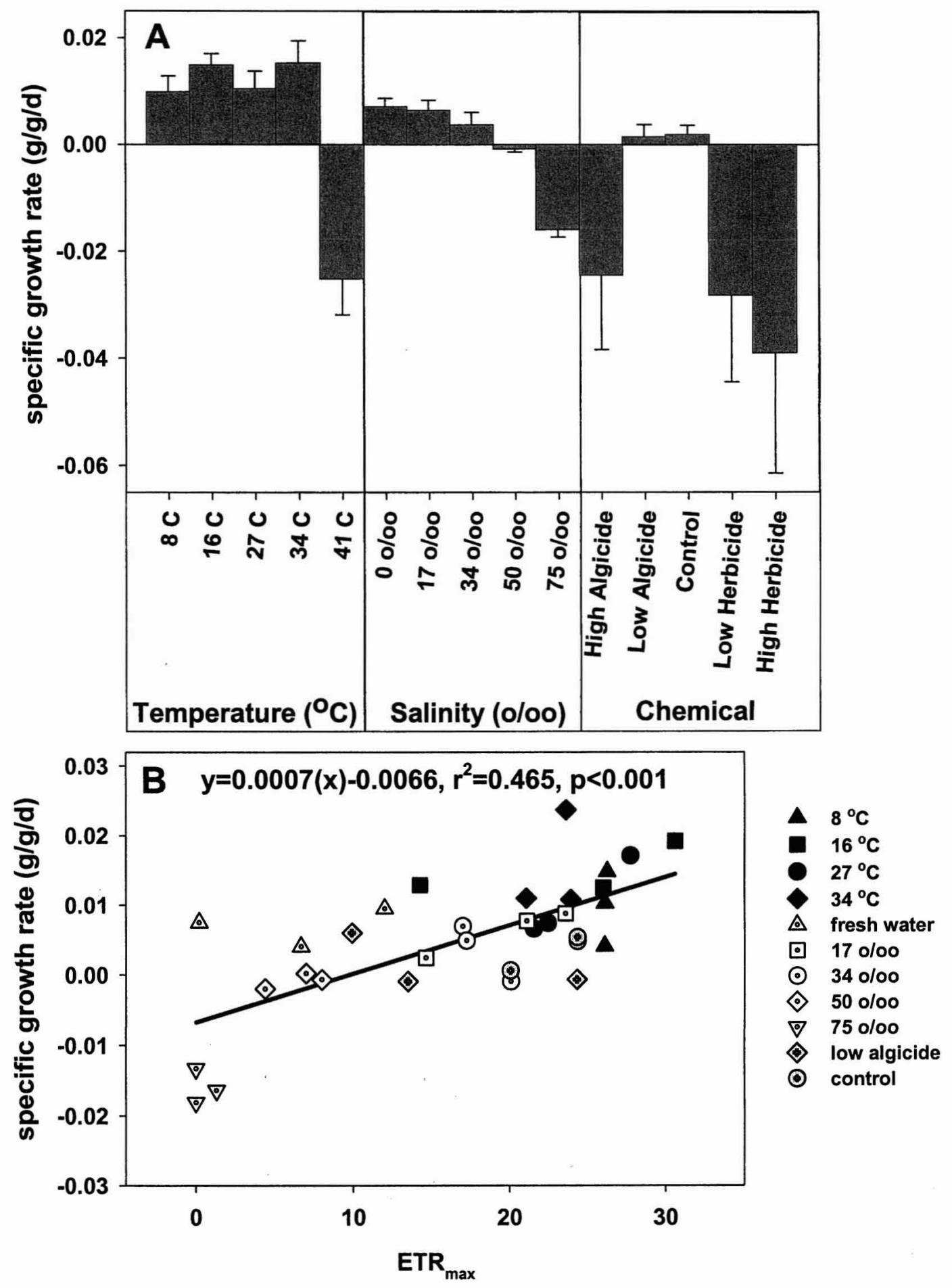

FIGURE 6. $A$, Growth rates (g/g/day) of $G$. salicornia under different experimental treatments (mean $\pm 1 \mathrm{SE}, n=3$ ); $B$, linear regression relating growth rates to $\mathrm{ETR}_{\max }$. 


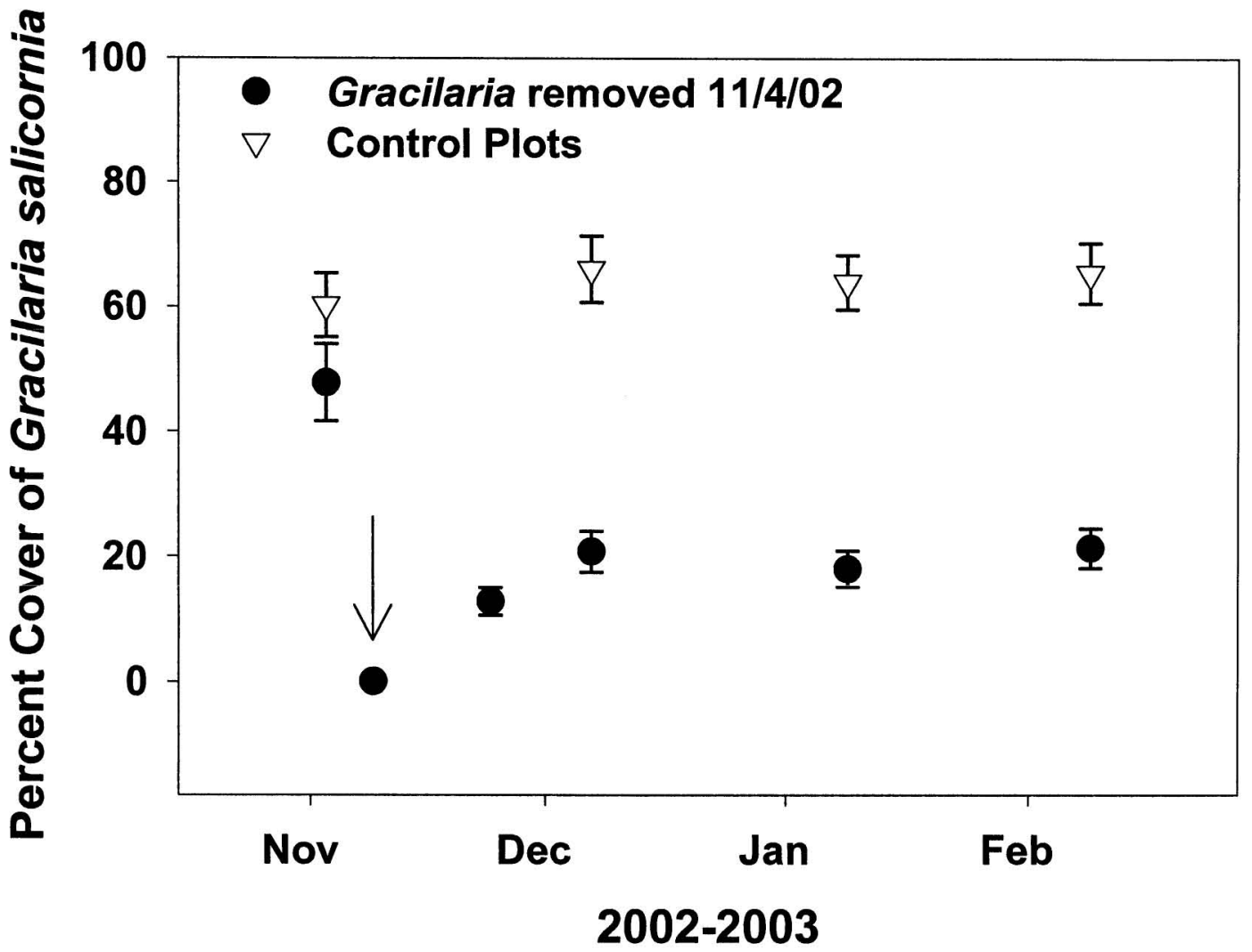

FIgURE 7. Mean percentage cover $( \pm 1 \mathrm{SE}, n=15)$ of $G$. salicornia from three transects in front of the Natatorium in both control and removal plots. Gracilaria salicornia was removed on 4 November 2002 (see arrow), and percentage cover was monitored in both plot types for approximately 3 months. Open triangles represent control plots; closed circles represent removal plots before and after clearing.

$P=0.137)$. Significant linear regression relationships were established for time to clear, percentage cover, and biomass per square meter. Despite a wide variation in the thickness of $G$. salicornia mats, percentage cover and biomass had a significant positive association. Percentage cover was a better predictor than biomass for the time required to clear plots (Figure $8 A-C$ ).

\section{Volunteer-Based Nonindigenous Marine Algae Removal Efforts}

In the five nonindigenous algae cleanups at the Waikiki MLCD to date (each 4 to $5 \mathrm{hr}$ in duration), over $20,000 \mathrm{~kg}$ of $\mathrm{G}$. salicornia biomass was removed from the trench and/or the beach and recycled (Table 1). The total effort involved over 400 volunteers donating a total of approximately 2000 person-hours. The use of the beach seine in the last three cleanups greatly increased the biomass of small fragments removed from the beach and adjacent reef flat.

\section{DISCUSSION}

Despite the number of nonindigenous marine algae that have been introduced to Hawai'i's coral reefs for aquaculture over the last several decades, little research has been conducted on the potential impacts of these species in their new environments (but see Russell 1983, 1987, 1992, Rodgers and Cox 

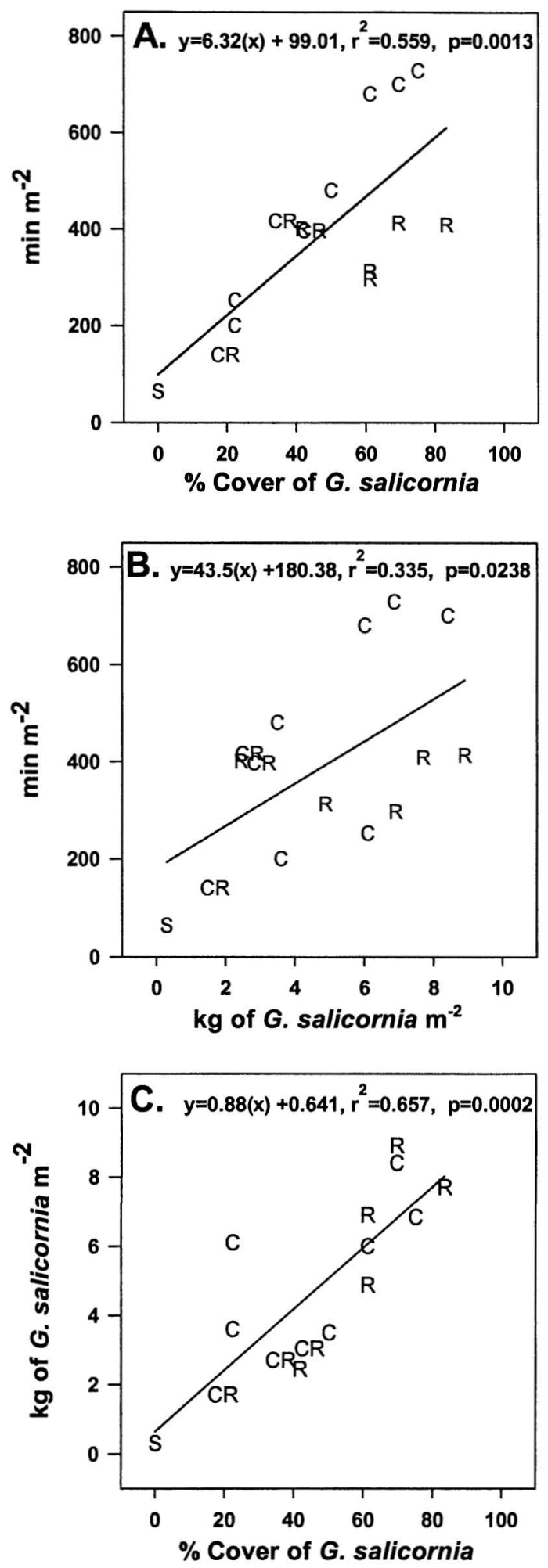

1999, Woo 2000, and Smith et al. 2002). Zemke-White (in press) conducted a worldwide study investigating the environmental impacts of seaweed farming in the Tropics and found that although some 39 species from 15 genera are cultured in 22 countries, a comprehensive study on the impacts, escape, establishment, and interaction of these algae with native flora and fauna has never been undertaken. The field of invasion biology continues to progress in a number of terrestrial and aquatic ecosystems, but impacts of introduced macroalgae in the Tropics remain largely unknown and are in need of more research.

Results from our study provide a number of insights into the ecology and basic biology of the invasive alga $G$. salicornia in Hawai'i. Reconnaissance surveys showed that this alga has increased in distribution in just 2 yr. Gracilaria salicornia was initially introduced to the reef flat in front of the Natatorium in Waikiki in 1971 and has since spread both east and west approximately $2.5 \mathrm{~km}$. Populations located at Ala Moana Beach Park have established during the last 2 yr (not present in surveys conducted by Smith et al. 2002), suggesting that this species is continuing to spread. Because G. salicornia reproduces primarily through vegetative propagation in Hawai'i (Nishimura 2000, Smith et al. 2002), a number of factors may contribute to such high rates of spread. Any sort of physical disturbance can generate fragments, including wave action, fish bites, and trampling, and once these propagules are generated they most likely disperse through currents and other hydrodynamic events such as large swell. Fragments may also be spread by transport through the guts of herbivorous fishes, urchins, or sea turtles (Russell and Balazs 1994). More research is needed to determine if fragments are viable after passage through

FigURE 8. Linear regression relationship between: $A$, manual time to clear $\mathrm{m}^{2}$ plot of $G$. salicornia and biomass per $\mathrm{m}^{2} ; B$, manual time to clear $\mathrm{m}^{2}$ plot of $G$. salicornia and percentage cover of $G$. salicomia; $C$, relationship between biomass and percentage cover of $G$. salicornia. Letter symbols in each figure represent different habitat types: $\mathrm{C}$, crevices; $\mathrm{R}$, rubble; $\mathrm{S}$, sand. 
TABLE 1

Total Number of Volunteers and Biomass of Algae (Wet Weight in kg) Removed from Both Trench and Beach Wash for Each Volunteer Cleanup Event

\begin{tabular}{lcrcr}
\hline \hline & & \multicolumn{3}{c}{ G. salicornia Biomass Removed (kg) } \\
\cline { 3 - 5 } Cleanup Event & Volunteers & Trench & Beach & Total \\
\hline 24 Aug. 2002 & 62 & $1,995.2$ & 411.6 & $2,406.8$ \\
21 Sept. 2002 & 82 & $2,693.1$ & 391.4 & $3,084.5$ \\
16 Nov. 2002 & 105 & $2,648.4$ & $2,344.8$ & $4,993.2$ \\
1 Feb. 2003 & 118 & $2,478.4$ & $3,128.6$ & $5,607.0$ \\
5 Apr. 2003 & 120 & $2,762.7$ & $1,648.0$ & $4,410.7$ \\
Total to date & 487 & $12,577.8$ & $7,924.4$ & $20,502.2$ \\
\hline
\end{tabular}

the guts of vertebrate and invertebrate grazers. New human-mediated intentional introductions of $G$. salicornia around Hawai'i are still possible; G. salicornia is now commonly found in poke (a local raw fish salad) and is sold at a number of local markets around O'ahu.

Because of prevailing trade winds from the northeast, spread of fragments from the $\mathrm{Na}$ tatorium down the coast in a westerly direction seems likely. Although this does appear to be the case, G. salicornia has also spread upcurrent to Diamond Head in a direction against the trade winds. It is unclear how the population at Hawai'i Kai originated, but it most likely came from Waikikī rather than Kāne'ohe because of the direction of the trade winds and expanses of deep water along the eastern shore north of Hawai'i Kai.

Studies conducted in Kāne'ohe Bay by Rodgers and Cox (1999) in 1996 found little to no $G$. salicornia in the northern portion of the bay. Smith et al. (2002) conducted similar surveys in 2000 and found G. salicornia at two locations in the north bay. In 2002, we documented $G$. salicornia outside the north bay at Kualoa Beach Park. Evidence from the recent surveys suggests that $G$. salicornia is still spreading and rates of dispersal appear to be increasing. As new populations emerge, more biomass is available for fragmentation and subsequent dispersal. Without intervention, this species is highly likely to continue invading new sites.

We have documented a positive relationship between swell height and the amount of
G. salicornia that washes up on the beach in front of the Waikiki Aquarium at low tide. Over $1814.4 \mathrm{~kg}$ of wet-weight biomass was recorded on the beach after a $1.45-\mathrm{m}$ swell in less than a $120-\mathrm{m}^{2}$ area. Such extensive accumulations of algae washed ashore can prevent beachgoers from utilizing this area and because this beach is located in Waikīkin, one of the most popular tourist destinations in the world, it seems likely that G. salicornia could have an economic impact on O'ahu. In a recent economic valuation conducted by Cesar et al. (2002), net losses exceeding \$20 million per year were quantified for the island of Maui because of problems associated with the alien alga Hypnea musciformis. Maui County spends hundreds of thousands of dollars per year removing rotting algal biomass from beaches, and property value and hotel occupancy rates have decreased in these "algae zones." Effective removal programs are being developed by resource managers in those areas to reduce local impacts. Economic studies are becoming increasingly important because they can provide researchers and managers with the monetary leverage (dollar value of a given reef, for example) that is often needed to protect marine resources.

In Waikikī, not only do thousands of kilograms of algae wash up onto the beach, but at high tide this material is washed back out onto the reef where it can regrow and disperse to adjacent reef areas. Results from our field growth experiments show that these fragments remain viable after more than 6 $\mathrm{hr}$ of desiccation. Although the beach wash 
fragments in both experiments grew less than fragments collected from attached plants on the reef, they were all still viable. Because removal of algae is much easier on shore than it is in the water, a partial solution would be to have beach cleanups at low tide, especially on days following large south swells when a large amount of beach wash is present. Such a strategy would not control $G$. salicornia, but it could help to reduce the amount of viable propagules circulating on reefs.

Several control strategies were examined in this study, including possible herbivore enhancement, mechanisms to kill algae in situ (chemical, temperature, and salinity), and manual removal in an effort to develop the most effective management tools to reduce or remove G. salicornia on Hawai'i's reefs. Based on herbivore preference tests, the fish species examined here preferred the native Gracilaria species over the alien, with consumption rates for the native species over eight times that for the alien. More work is needed to understand food preferences (Hay et al. 1994) for other grazers such as sea urchins, crustaceans, mollusks, and turtles, but our results suggest that enhancing fish stocks in these invaded areas may not significantly alter alien algal community dynamics, especially if other preferred native species are present.

Based on three experiments investigating the potential use of temperature, salinity, and chemicals to kill $G$. salicornia, our results show that this species is remarkably resilient. In the temperature experiment, only the extremely warm seawater treatment $\left(41^{\circ} \mathrm{C}\right)$ killed the alga. In the salinity experiment, only the saltsaturated solutions (75\%) and the 50\% treatments caused mortality, and the alga thrived in conditions ranging from freshwater to ambient seawater conditions. The chemical treatment showed the highest degree of mortality overall, with only samples in the low algicide treatments surviving. The ability of this alga to tolerate such extreme conditions is remarkable and shows a wide range of adaptation that allows this species to survive in environments where temperatures may fluctuate throughout a range of conditions from cool freshwater runoff to warm hyposaline intertidal areas. These experiments are useful to show the robustness of this invasive alga, but implementation of any of these treatments in the field is not practical because of the collateral damage that would occur to other reef organisms, especially corals. The treatment that will be examined further is the use of high salinity by administering rock salt to the benthos, a treatment that is being used in New South Wales, Australia, to kill the invasive alga Caulerpa taxifolia (M. Vahl) C. Agardh (A. Millar, pers. comm.). Future research should examine the effects of elevated salinity on other reef organisms.

Manual removal of $G$. salicornia is currently the most feasible control strategy available. Even so, this technique is extremely time-consuming (6.9 person-hours per square meter); preliminary evidence suggests that $G$. salicornia will regrow rapidly from the substratum where small attachment points are left behind. The removal activity itself inevitably generates fragments, not all of which can be captured, and these can disperse and potentially regrow. More long-term data are needed to determine how successful the regrowth of $G$. salicornia is from basal attachment points, but it seems likely that some combination of strategies will be needed to effectively control this invasive alga. When clearing plots by hand the majority of time is spent removing small basal attachment points from the substratum with forceps while only about one-tenth of the time is spent removing the large conspicuous biomass. If some other technique such as temporary herbivore (sea urchin) enhancement or the use of salt or other techniques could be used to remove these small but viable pieces of tissue, largescale control of G. salicornia may be possible.

Removal of unattached and drifting but still viable G. salicornia biomass from Waikìkī was a logical first step for large-scale removal activities. Because of increased concern and interest, a large group of volunteers was assembled and enthusiastic about removing this alien alga. But because of the difficulties in removing attached biomass mentioned earlier, it was decided that these initial large-scale efforts would focus on removing the floating fragment pool as well as the beach wash. These activities were justified by the fact that 
even if removal activities generated some fragments, substantially more fragments were removed than were generated. These activities have been successful in removing a large amount of biomass from the reef and the trench, but we have yet to clear all of the drifting fragments completely. We are currently in the process of designing an underwater suction device that we hope will help to speed up the process of removing drift algae.

In conclusion, $G$. salicornia is a robust, successful, and remarkably resilient invader of Hawai'i's reefs. We believe that without intervention, this species will continue to spread around the island of $\mathrm{O}^{\prime}$ ahu and is likely spreading on the islands of Moloka' $i$ and Hawai'i. A multifaceted approach is needed to develop a successful control program and will likely involve a combination of manual removal, grazer enhancement, and/or use of rock salt as well as a suction device to contain fragments that may be generated during the removal process. In reef areas where this invader is present, it occupies over $50 \%$ of the substratum and is clearly having an impact on native species diversity and benthic community dynamics; but more research is needed to investigate these impacts, interactions, and potential implications. This invasive species is most likely having both ecological and economic impacts in the Hawaiian Islands and, therefore, control and mitigation should be a priority for both state and federal marine resource managers. Coral reefs worldwide are threatened by a number of anthropogenic factors including overfishing and eutrophication (Littler and Littler 1984, Lapointe 1997, McClanahan 1997, Miller et al. 1999, McClanahan et al. 2001, McCook et al. 2001, Smith et al. 2001, Stimson et al. 2001, Thacker et al. 2001); future research should investigate the impacts of invasive nonindigenous marine algae on coral reef community structure and how herbivores and/or nutrients influence these interactions.

\section{ACKNOWLEDGMENTS}

We thank Scott Atkinson and Eric Co from The Nature Conservancy; Matt Zimmerman from Reef Check Hawai'i; Randy Honebrink,
Dave Gulko, Mike Markrich, and Bill Devick from the Hawai' $i$ Department of Land and Natural Resources; and numerous volunteers for their invaluable help in the field.

\section{Literature Cited}

Andrew, N. L., and R. M. Viejo. 1998. Ecological limits to the invasion of Sargassum muticum in northern Spain. Aquat. Bot. 60:251-263.

Beach, K. S., H. B. Borgeas, N. J. Nishimura, and C. M. Smith. 1997. In vivo absorbance spectra and the ecophysiology of reef macroalgae. Coral Reefs. 16:21-28.

Bellan-Santini, D., P. M. Arnaud, G. Bellan, and M. Verlaque. 1996. The influence of the introduced macroalga Caulerpa taxifolia on the biodiversity of the Mediterranean marine biota. J. Mar. Biol. Assoc. U.K. 76:235-237.

Carlton, J. T. 1987. Patterns of transoceanic marine biological invasions in the Pacific Ocean. Bull. Mar. Sci. 41:452-465.

Carlton, J. T., and J. B. Geller. 1993. Ecological roulette: The global transport of nonindigenous marine organisms. Science (Washington, D.C.) 261:78-82.

Carlton, J. T., and J. A. Scanlon. 1985. Progression and dispersal of an introduced alga: Codium fragile on the Atlantic coast of North America. Bot. Mar. 28:155-165.

Cesar, H. S. J., P. J. H. van Beukering, W. Pintz, and J. Dierking. 2002. Economic valuation of the coral reefs of Hawai'i. Hawai'i Coral Reef Initiative, University of Hawai'i, Honolulu.

Coles, S. L., R. C. DeFelice, L. G. Eldredge, and J. T. Carlton. 1997. Biodiversity of marine communities in Pearl Harbor, Oahu with an emphasis on introduced exotic species. Bernice P. Bishop Mus. Tech. Rep. 10.

. 1999. Historical and recent introductions of non-indigenous marine species into Pearl Harbor, Oahu, Hawaiian Islands. Mar. Biol. (Berl.) 135:147-158.

Critchley, A. T., W. F. Farnham, and C. H. Thoro. 1997. On the co-occurrence of two exotic, invasive marine organisms: The brown seaweed Sargassum muticum and the 
spirorbid tube worm fanua brasiliensis in association with the indigenous eelgrass Zostera marina and Fucus serratus in the southwest Netherlands and the Channel Islands, Europe. S. Afr. J. Bot. 63:474-479.

Doty, M. S. 1969. The standing crop of benthic frondose algae at Waikiki Beach 1966 -1969. Hawaii Bot. Sci. Pap. 11.

Eldredge, L. G., and C. M. Smith. 2001. A guidebook to introduced marine species in Hawai'i. Bernice P. Bishop Mus. Tech. Rep. 21.

Ferrer, E., A. G. Garreta, and M. A. Ribera. 1997. Effect of Caulerpa taxifolia on the productivity of two Mediterranean macrophytes. Mar. Ecol. Prog. Ser. 149:279287.

Frenette, J. J., S. Demers, L. Legendre, and J. Dodson. 1993. Lack of agreement among models for estimating the photosynthetic parameters. Limnol. Oceanogr. 38:679687.

Friedlander, A. M., J. D. Parrish, and R. C. DeFelice. 2002. Ecology of the introduced snapper Lutjanus kasmira in the reef fish assemblage of a Hawaiian bay. J. Fish Biol. 60:28-48.

Hanisak, M. D. 1980. Codium: An invading seaweed. Maritimes 24:10-11.

Hay, M. E., Q. E. Kappel, and W. Fenical B. 1994. Synergisms in plant defenses against herbivores: Interaction of chemistry, calcification and plant quality. Ecology 75: 1714-1726.

Hodgson, L. M. 1994. Maui algae project. A technical report submitted to Hawai'i Department of Health, Environmental Planning Office, Honolulu.

Holmlund, M. B., C. H. Peterson, and M. E. Hay. 1990. Does algal morphology affect amphipod susceptibility to fish predation? J. Exp. Mar. Biol. Ecol. 139:65-83.

Jousson, O., J. Pawlowski, L. Zaninetti, F. W. Zechman, F. Dini, G. Guiseppe, R. Woodfield, A. Millar, and A. Meinesz. 2000. Invasive alga reaches California. Nature (Lond.) 408:157-158.

Karlsson, J., and L. Loo. 1999. On the distribution and the continuous expansion of the Japanese seaweed Sargassum muticum in Sweden. Bot. Mar. 42:285-294.
Lapointe, B. 1997. Nutrient thresholds for eutrophication and macroalgal blooms on coral reefs in Jamaica and Southeast Florida. Limnol. Oceanogr. 42:1119-1131.

Larned, S. T. 1998. Nitrogen versus phosphorus limited growth and sources of nutrients for coral reef macroalgae. Mar. Biol. (Berl.) 132:409-421.

Littler, M. M., and D. S. Littler. 1984. Models of tropical reef biogenesis: The contribution of the algae. Prog. Phycol. Res. $3: 323-364$.

Maragos, J. E., M. E. Crosby, and J. W. McManus. 1996. Coral reefs and biodiversity: A critical and threatened relationship. Oceanography 9:83-99.

McClanahan, T. R. 1997. Primary succession of coral reef algae: Differing patterns on fished vs. unfished reefs. J. Exp. Mar. Biol. Ecol. 218:77-102.

McClanahan, T. R., M. McField, M. Huitric, K. Bergman, E. Sala, M. Nyström, I. Nordemar, T. Elfwing, and N. A. Muthiga. 2001. Responses of algae, corals and fish to the reduction of macroalgae in fished and unfished patch reefs of Glovers Reef Atoll, Belize. Coral Reefs 19:367379.

McCook, L. J., J. Jompa, and G. Diaz-Pulido. 2001. Competition between corals and algae on coral reefs: A review of evidence and mechanisms. Coral Reefs 19:400-417.

Meinesz, A., J. De Vaugelas, B. Hesse, and X. Mari. 1993. Spread of the introduced tropical green alga Caulerpa taxifolia in northern Mediterranean waters. J. Appl. Phycol. 5:141-147.

Miller, M. W., M. E. Hay, S. L. Miller, D. Malone, E. E. Sotka, and A. M. Szmant. 1999. Effects of nutrients versus herbivores on reef algae: A new method for manipulating nutrients on coral reefs. Limnol. Oceanogr. 44:1847-1861.

Nishimura, N. J. 2000. Assessment of genetic variability in the invasive red alga $\mathrm{Gra}$ cilaria salicornia using multi-locus DNA fingerprinting. M.S. thesis, University of Hawai'i at Mānoa, Honolulu.

Peterson, C. H., and P. Renaud. 1989. Analysis of feeding preference experiments. Oecologia (Berl.) 80:82-86. 
Rodgers, S. K., and E. F. Cox. 1999. Rate of spread of introduced rhodophytes Kappaphycus alvarezii, Kappaphycus striatum, and Gracilaria salicornia and their current distributions in Kāne'ohe Bay, O'ahu, Hawai'i. Pac. Sci. 53:232-241.

Ruiz, G., M. P. Fofonoff, and A. H. Hines. 1999. Nonindigenous species as stressors in estuarine and marine communities: Assessing invasion impacts and interactions. Limnol. Oceanogr. 44:950-972.

Russell, D. J. 1983. Ecology of the red imported seaweed Kappaphycus striatum on Coconut Island, Oahu, Hawai'i. Pac. Sci. 37:87-107.

- 1987. Introductions and establishment of alien marine algae. Bull. Mar. Sci. 42:641-642.

. 1992. The ecological invasion of Hawaiian reefs by two marine red algae: Acanthophora spicifera and Hypnea musciformis and their association with two native species Laurencia nidifica and Hypnea cervicornis. ICES Mar. Sci. Symp. 194:110-125.

Russell, D. J., and G. Balazs. 1994. Colonization by the alien marine alga Hypnea musciformis (Wulfen) J. Ag. (Rhodophyta: Gigartinales) in the Hawaiian Islands and its utilization by the green turtle, Cbelonia mydas. Aquat. Bot. 47:53-60.

Schaffelke, B., M. L. Campbell, D. F. Millie, and P. Kurgens. 2000. Introduced macroalgae in the Australian region: Current state of knowledge. J. Phycol. 36:61.

Smith, J. E., C. M. Smith, and C. L. Hunter. 2001. An experimental analysis of the effects of herbivory and nutrient enrichment on the benthic community composition of a Hawaiian reef. Coral Reefs 19:332342.

Smith, J. E., C. L. Hunter, and C. M. Smith. 2002. Distribution and reproductive characteristics of nonindigenous and invasive marine algae in the Hawaiian Islands. Pac. Sci. 56:299-315.

Smith, S. V., W. J. Kimmerer, E. A. Laws, R. E. Brock, and T. W. Walsh. 1981. Kaneohe Bay sewage diversion experiment: Perspectives on ecosystem responses to nutritional perturbation. Pac. Sci. 35:279395.
Stiger, V., and C. E. Payri. 1999a. Spatial and temporal patterns of settlement of the brown macroalgae Turbinaria ornata and Sargassum mangarevense in a coral reef on Tahiti. Mar. Ecol. Prog. Ser. 191:91-100. 1999b. Spatial and seasonal variations in the biological characteristics of two invasive brown algae, Turbinaria ornata (Turner) J. Agardh and Sargassum mangarevense (Grunow) Setchell (Sargassaceae, Fucales) spreading on the reefs of Tahiti (French Polynesia). Bot. Mar. 42 (3): 295306.

Stimson, J., S. T. Larned, and E. J. Conklin. 2001. Effects of herbivory, nutrient levels, and introduced algae on the distribution and abundance of the invasive macroalga Dictyosphaeria cavernosa in Kaneohe Bay, Hawai'i. Coral Reefs 19:343-357.

Stone, R. 1999. Keeping paradise safe for the natives. Science (Washington, D.C.) 285: 1837.

. 2002. A plan to save Hawaii's threatened biodiversity. Science (Washington, D.C.) 285:817.

Thacker, R. W., D. W. Ginsburg, and V. J. Paul. 2001. Effects of herbivore exclusion and nutrient enrichment on coral reef macroalgae and cyanobacteria. Coral Reefs 19:318-329.

Trowbridge, C. D. 1995. The establishment of the green alga Codium fragile on New Zealand rocky shores: Current distribution and invertebrate grazers. Ecology 83:949965.

White, A. J., and C. Critchley. 1999. Rapid light curves: A new fluorescence method to assess the state of the photosynthetic apparatus. Photosynth. Res. 59:63-72.

Woo, M. 2000. Ecological impacts and interactions of the introduced red alga Kappaphycus striatum in Kāne'ohe Bay, O'ahu. M.S. thesis, University of Hawai'i at Mānoa, Honolulu.

Zemke-White, W. L. in press. Assessment of the current knowledge on the environmental impacts of seaweed farming in the tropics. Proceedings of the Asia-Pacific Conference on Marine Science and Technology, 12-16 May 2002, Kuala Lumpur, Malaysia. 